\title{
REFURBISHMENT OF GURDWARA BABA BHUMAN SHAH DIPALPUR, DISTRICT OKARA
}

\author{
Asia Jabeen \\ Assistant Professor, Architecture Department, \\ LCWU Lahore, Punjab, Pakistan. \\ asiajabeen@ymail.com \\ Mazhar Munir \\ Chief Executive, Mazhar Munir Designs, \\ Lahore, Punjab, Pakistan \\ newctmc@gmail.com
}

\begin{abstract}
Historical monuments represent the significant features of culture, religion, economic conditions, and social values of the period in which they have been developed. The core objective of the research article is to explore the architectural and historical importance of the Gurdwara Baba Bhuman Shah Complex which is one and only example of historic monuments of Udasi clan in Pakistan. This complex is included group of buildings such as Darbar/Gurdwara, Smadhs of Baba Bhuman Shah and his Mahants, Nishan Sahib, Thara and Deori (gateway). Udasi clan is running parallel to Sikhism facing all the warm winds and supported to protect Sikh Gurdwaras during the eighteenth century when Sikhs were under the persecutions. The selected case study dates back more than two hundred years and has been declared as National Heritage Site by the Government of Pakistan in 2008. The complex has been ruined due to the negligence and human vandalism. The focus is to save this significant historic complex for the study of future generations. Restoration of built heritage of Udasi Panth is the key element for the sustainable development of the area.
\end{abstract}

Keywords: Conservation, Restoration, Gurdwara Baba Bhuman Shah, Udasi Heritage.

\section{INTRODUCTION}

In this world of rapid urbanization, refurbishment of built heritage has become a great challenge and sustainable developments are the core objectives of the Department of Archaeology. The research article focuses to understand the need for the conservation and restoration of the Gurdwara Baba Bhuman Shah who was great devotee of Baba Sri Chand, founder of Udasi Panth in India. Bhuman Shah was born in Behlolpur village, Tehsil Dipalpur, District Okara on April 14, 1687 CE. Saint and his family were admirers of Baba Sri Chand who was elder son of Baba Guru Nanak, (Kamboj, 2002)

The complex was initially a residential place of Baba Bhuman Shah. After his death, his successor Baba Nirmal Chand erected his Smadh at the same place. There are Smadhs of Baba Nirmal Chand and his other Mahants in the adjacent area. In the complex, there is a Darbar/Gurdwara named Darbar Baba Sri Chand, Smadh of Baba Bhuman Shah and Smadhs of various mahants, successors of Baba Bhuman Shah. In the courtyard, there is a Thara (for recitation of Holy verses), Nishan Sahib (place for flag) and Deory (gateway to the complex). Darbar has been an addition during the British period. In the context of the Gurdwara, there is a Haveli, residence of Baba Bhuman Shah and a Dharmshala consisting of hundreds of rooms for the pilgrims and visitors, lunger Khana and a tank. The whole complex is termed as Dera Baba Bhuman Shah (Kapoor, 2000)

Bhai Kahan Singh says that a Saint Dashmesh had blessed Baba Bhuman with a consecration that his lunger will be continued serving even after his death. Baba was buried at that place and a shrine was constructed with four doors to enter and walls covered with colorful pictures and sayings of the Gurus.

The building is unique with reference to its distinctive style and architectural features. As per a report prepared by Evacuee Trust Punjab Board, the total landed property in the name of shrine and Gurdwara was over 1800 acres of agricultural land which was transferred in the name of Gurdwara 
Baba Nanak Sheikhupura. Other than landed property, this Dera has owned moveable and immoveable property.

Sikh Gurdwaras and Sikh Shrines present true picture of Sikh architecture which itself has been derived by the Mughal Architecture as the artisan of that period has been trained for the Mughal elements of Architecture. However, Sikh architecture evolved its significant features such as chatris, onion dome, and ornamentation on parapets, eaves, corners, and angles with the use of frescos with the passage of time (Brown, 2002)

Gurdwaras are the type of Sikh heritage which explores largely architectural elements and ornamentations. Sikh Gurdwaras are of three types, connected with Sikh Gurus, Sikh Martyrs and Sikh saints. All of these three Gurdwaras contain all the architectural design elements such as Provision of Parkash Asthan, a congregation Hall and a Sukh Asthan/Congregation Hall. After Baba Guru Nanak, Sikhism divided into many Panths/sects and Baba Sri Chand, elder son of Baba Guru Nanak started to focus on Hinduism and added Hindu rituals to his new Panth and named his clan "Udasi Panth or Nanak Putras" which means sons of Guru Nanak. Udasi's also say hymens of Guru Granth sahib, sacred book of Sikhs (Baig, 2016).

Udasi Gurdwaras are associated with Saints, and they are termed as Temple/Mandir after the Sikh Reforms Act 1925. Baba Bhuman Shah is the follower of Baba Sri Chand and was famous due to his spiritual powers in the area. Udasis believe in preaching of Baba Nanak through his elder son Baba Sri Chand and have their own Deras and monasteries in the whole sub-continent. During the eighteenth century when Sikhs were under persecutions by the Mughals, they were the Udasis who protected the Sikh places of worships/ Gurdwaras (Singh P. A., 1986).

During the Akali movement, Khalsa Sikhs expelled them out of their Gurdwaras and took the charge as per Sikh Gurdwara Reform Act 1925 passed by the British Government. In these reforms, Udasis were declared as non-Sikhs and excluded from Sikhisms (Singh, 2020).

Dera Baba Bhuman Shah is the only example of Udasi Heritage in Pakistan containing of Smadhs of Baba Bhuman Shah and his various Mahants. After Independence, the caretaker of the Dera moved to India leaving the place not operational for religious purposes. Currently, the whole complex is under the umbrella of Evacuee Trust Punjab Board. Gurdwara Purbandhak Committee is also responsible for his protection because the Gurdwara has been added in the list of National Heritage in Pakistan (Qaiser, 1998)

At present, the Gurdwara has been transformed in ruins and is a live example of negligence and human Vandalism. There are huge mounds of filth and garbage all around the monument. In 2005, Gurdwara has been preserved on the request of Baba Braham Das, a Mahant in Haryana. Smadhs of Baba Bhuman Shah and his Mahants was declared as National Heritage Site in 2008. In 2009, another effort was done to protect monument but in vain (Wikipedia, 2021).

The Gurdwaras are multifunctional places of the Sikhs and the vital part of their lives. The core function is worship. The associated places are Dharamshala's, rest houses for travelers. Guru Granth Sahib has also been placed in the Gurdwaras. Sikh ruled over sub-continent for less than a century, but they constructed hundreds of Gurdwaras in sub-continent.

With the passage of time, we have realized the importance of our built heritage, irrespective of religion and sects. Very little work has been done to explore Sikh heritage and nothing has been done for Udasi monuments. Unfortunately, Sikh legacy has been ignored and neglected. If this National Heritage left ignored, we would lose the last treasure of Udasi Panth in Pakistan.

\section{REVIEW OF LITERATURE}

The research focuses on the Sikhism and its sects. The architectural characteristics of Sikh built heritage which is on grave threat in Pakistan due to number of facts such as negligence, human vandalism, weather impacts and unawareness about the importance of historic monuments.

\section{Sikhism}

Guru Nanak was founder of Sikh religion in Punjab region of Northern India about 500 years ago. Initially, it was considered something in between Hinduism and Islam. Later, it was known as an independent religion of its own believes and faiths which couldn't be compared with any other religion. The Sikh religion has ten Prophets named as Gurus and Baba Guru Nanak. The period starts from 1469 to 1708. Sikh religion rejects idol worship, caste system and asceticism. It supports gender 
equality, truthfulness and honesty whereas preclude the use of intoxicants, drinking and smoking. Guru Granth Sahib is their Holy Book which stands for supreme spiritual guidance. The Gurus are not worshipped, instead, they worship only one God called Wahe Guru - Wonderful God (TheSikhEncyclopedia.com, 2000).

Sikhism evolved in the lands of Punjab and spread all over the globe. Singh-the lion is the title given to the male members of the community and Kaur-princes is the family name for females. Sikhs are hard-working and sturdy due to fights; they have to fight for their survival.

\section{The Sects of Sikh}

The early Sikh sects are Udasis founded by Baba Sri Chand, elder son of Baba Guru Nanak and Minas founded by Baba Prithi Chand, elder son of Baba Ram Das (Forth Guru) in the presence of Sikh Gurus. Ram Rai, son of Guru Har Rai founded a new sect with the name of Ramraiyas at Dehradun Namdharis and Nirankaris also categories of Sikh sect (https://en.wikipedia.org/wiki/Sikh, 2016).

\section{Udasi}

Udasi is a Sikh sect belong to Sadhus, who accepts Sikh Gurus but give more importance to Baba Sri Chand. They believe in the messages of Guru Granth sahib in vedantic terms rather to follow Khalsa's Rehat Maryads.

\section{Basics of Sikhism}

Baba Guru Nanak is the founder of Sikh religion, history dates back 1469 was born in a village called Talwandi, now renamed as Nankana Sahib in Pakistan. Sikh has ten prophets termed as Gurus. First one is Baba Guru Nanak and tenth one is Guru Granth Sahib (Holy Book of Sikhs placed in Gurdwaras). Sikhs believes in One God and their common salutation is Sat Siri Akal- God is supreme and important. On the other hand, Udasis believe on Hindu gods also and the pictures of Hindu gods can be seen in the ornamentation of the Smadhs (Kapoor, 2000).

\section{Sikh Shrines}

Gurdwaras are the place of worship which means doorway to the house of God. Guru Nanak Dav constructed first Gurdwara at Kartarpur. In front of every Gurdwara, there was a flag termed as Nishan Sahib to prove the presence of Gurdwara for the travelers coming from far places. Guru Granth is in the congregational Hall. Langer Khana is also mandatory part of Sikh Gurdwaras to serve food for the pilgrims as Sikhism identify the concept of Pangat (Dining together) and sangat (congregation together). Pilgrims must cover the heads, taking off their shoes in front of Guru Granth. The food distributed is termed as Parshad (Kamboj, 2002).

According to Khushwant Singh says in his book "Sikh Architecture" that Sikh Gurdwara's can be predicament in all the other buildings due to its triangular flag mast (Nishan sahib) in yellow and blue color. Its domes are different to that of mosque and temple. Its arches, columns, balconies all are in unique style.

\section{Sikh Architecture}

Sikh community has many types of buildings such as Gurdwaras, palaces, Forts, Smadhs, Baolies, Havalies, Dharamshalas' and institutional Buildings. Sikh architecture majorly depicts its characteristics in its shrines, religious monuments. These places are not functions for worship but serve as centers of knowledge, art, and architecture. These buildings have socio-cultural impacts on the Sikh community. History reveals that Gurdwaras were initially called Dharamshal, the place for Sikh gatherings. After the death of Guru Granth in Dharamshal in 1604, it was named as Gurdwara, the holy place of Sikh community. The major functional areas of any Gurdwara are

- Congregation hall,

- Sukh ashan room

- Parkash asthan

- Parikaran

- Akand path area 
The fall of Mughal Empire resulted in the establishment of Sikh Empire in the sub-continent. During the eighteenth century, Maharaja Rant Singh enjoyed the throne and created an environment to think to elaborate artistic ideas. After securing the political powers, Sikh Gurdwaras were built on large scale. Institutional buildings such as offices, Sarai, residences for employees and museums were attached with main shrines. Sikh architecture was influenced by its surrounding area following Mughal and Hindu architectural elements. Punjab has played vital role in the evolution of Sikh architecture. During the period of Sikh rulers in Punjab, different art forms such as Naqqashi, Mohrakashi (Fresco), Jaratkari (Inlaid stone), Tukri work, Gach work and Gold Embossing were added. Like many other architectural styles, Sikh architecture is also the combination of previous architectural styles resulting a new style for itself (Brown, 2002).

\section{Udasi's Heritage}

The custodians of Udasi Gurdwaras were called mahants. They valued Adi Granth, respecting the Hindu five gods. After the settlement with the Sixth Guru Gobind, Baba Sri Chand got the favors of Guru Gobind and baptized his elder son Gurditta. During the eighteenth century, Udasis were not targeted by the rulers due to their power of preaching peace like the Khalsa's who are under persecution of the Mughal rulers. Out of ten Gurus, first five were the preachers of Sikh religion while rest are the fighters. called Khalsa (Kamboj, 2002).

After settlement all the issues with the rulers, Khalsa poured their attention towards Udasis who custodian of Sikh Deras was and Gurdwaras and enjoying all the wealth of these Gurdwaras. They felt uncomfortable and got declaration for Udasis as non-Sikhs explaining that they worship idols which Sikh don't. They supported their point of view by showing the idols of Baba Sri Chand and photographs of Hindu deities. Udasis constructs Smadhs/Mari inside the Gurdwaras/Mandirs which Sikh don't. Followers of Udasis are entitled as Chelas or Mahant instead Gurus. It has been declared by the court that Udasi are no more Sikhs now and is a sect in between Hindus and Sikhs (Baig, 2016).

\section{Dipalpur as a Historic City}

Dipalpur is an historic city developed about 2000 years ago and has been invaded multiple times. Ancient name of the city was Siri Puria or the Siri Nagar named after the name of Raja Salvahan who explored Sialot. The city was renamed Dipalpur on the name of Raja Depa Chand. Formerly, Dipalpur remained part of Montgomery District. In 1982, it was declared Tehsil of District Okara.

City was important after Multan due to historic events and historic monuments. It is also known for the battles fought during thirteen and fourteenth centuries. Okara is well known due to the Bhatti Clan. It is fortified city and its first fortification wall of 25 feet high (with a trench around the fortification) was constructed by Raja Depa Chand while crossing the city from Khyber Pass to Delhi. This fortification was renovated by Feroz Shah Tughlaq. Last renovation was done by Abdul Rahim Khan-e-Khanan, a Governor of Emperor Akber (Moon, 2016).

A canal from river Sutlej to irrigate gardens around the town. There were 24 Mosques, 24 ponds \& wells and 24 musketry holes in the city. Some of the trenches and ponds have been filled. Out of four gateways, two still exists but in ruined condition.

Other than all invasions, there is an historic event associated with the city is Visit of Baba Guru Nanak during his travel from Pakpattan Sharif to Talwandi. He stayed under a tree which was dead long time ago, but tree became green and alive due to his stay. He also treated some other people with his blessings.

The father of Baba Bhuman Shah has named his son as Bhumia in a family linkage Kamboj. His father Chaudhry Hassa Ram was a Numberdar and landlord of Behlolpur. The family is deeply devotees of Baba Guru Nanak through his son Baba Sri Chand. Later, his family moved to Dipalpur and settled in Kuttab Kot (Baig, 2016).

\section{RESEARCH METHODOLOGY}

Data has been collected through primary and secondary resources. Initially, electronic data has been collected through printed books, articles available online. The initial measured drawings have been provided by Department of Evacuee Trust Punjab Board through Mr. Arif Butt who supported my 
research at every step. Selected site was visited to do pictorial survey and image-based drawings have been prepared.

Research hierarchy defines the importance of Dera Baba Bhuman Shah with reference to the Historic City of Dipalpur. A detailed study has been done on Sikhism, Udasi Panth and their heritage sites. The Dera Baba Bhuman Shah is associated with an Udasi saint who was great follower of Baba Sri Chand, elder son of Baba Guru Nanak. Baba Bhuman Shah has his followers among Udasis, Sikhs and even Muslims due to his spiritual powers and blessings of God.

After collecting data, site survey and heritage inspection has been done through digital cameras and manual measurements has been completed. After that image-based drawings have been prepared to analyze the architectural spaces, elements and views.

An analysis has been done on the basis of collected data, interviews of the representative of Evacuee Trust Punjab Board, Lahore to prepare conservation and restoration plan of the Historic monument.

\section{Gurdwara Baba Bhuman Shah - Case Study}

Dera Baba Bhuman Shah is situated in the village Kuttab Kot, renamed after the name of Baba Bhuman Shah who baptize by Baba Pritam Das who was very significant Udasi Saint. Lakhas family

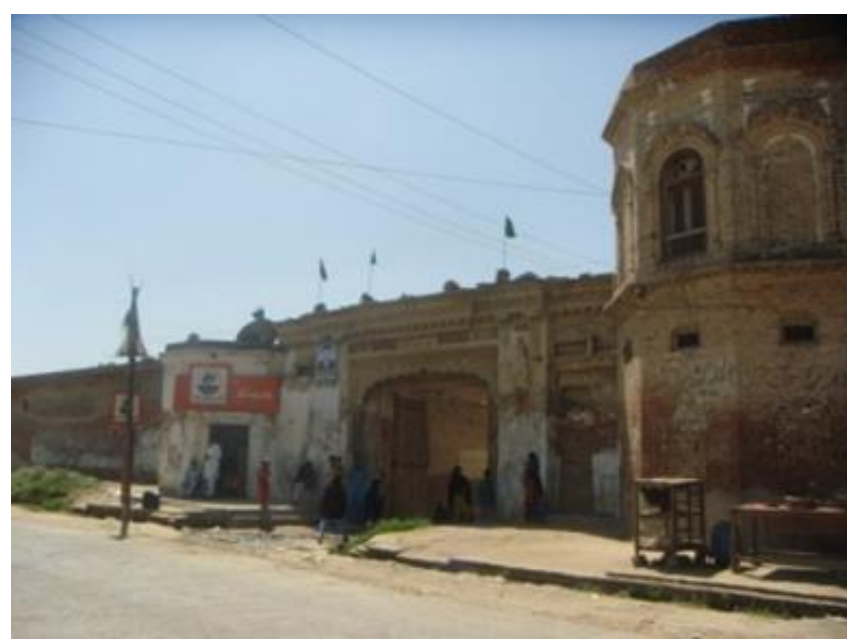

came out of trouble due to the spiritual powers of Baba Bhuman Shah and they gifted the Haveli to $\mathrm{Baba}$, and he started lunger Khana for the followers and travelers.

Figure 1 Boundary Wall o Dera Baba Bhuman Shah (By Author)

\section{Gurdwara Baba Bhuman Shah}

The selected monument is the central part of Dera Baba Bhuman Shah situated in the village Bhuman Shah, former name was Kuttab Kot who stayed here to convey the message of Baba Sri Chand. The village is located between Pakpattan Sharif and Dipalpur.

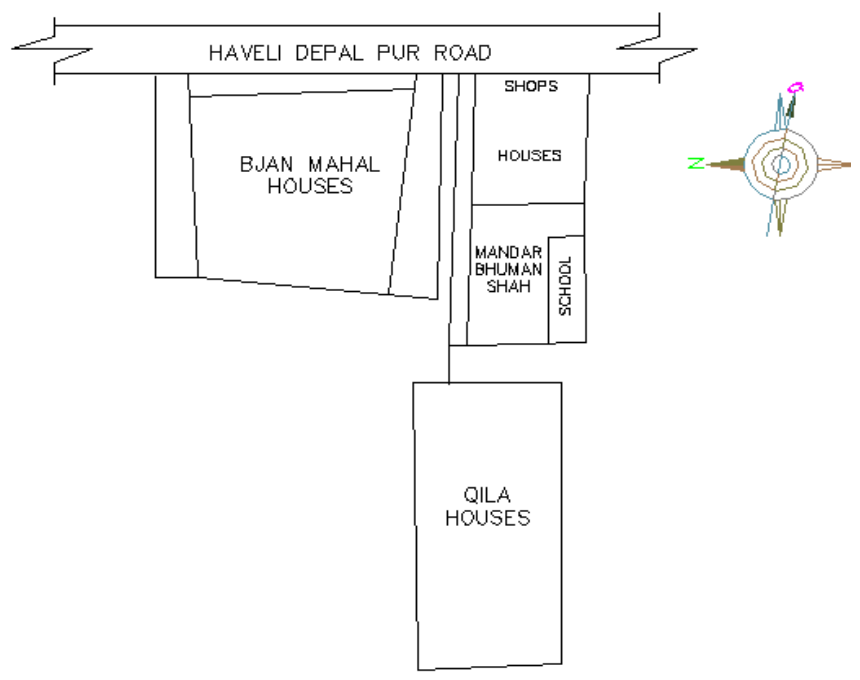


Number of miracles and myths are associated with the saint since his childhood. Lakhas family dedicated their Haveli in the favor of Baba Bhuman Shah when a family member of them has been released from a case due to the spiritual powers of Baba and moved towards a new place which was named as Haveli Lakh and the village was named after the name of Baba Bhuman Shah.

Baba Bhuman Shah consists of Bhajan Mahal, Haveli consisted of almost 200 Houses and Gurdwara Baba Bhuman Shah. The selected site is a part of Dera and has been converted into ruins as Gurdwara is no more functional and his Mahant has been moved to Northern India after Partition of Sub-continent. Outer wall of the Dera has been constructed like fort. There is a Dharamshala for the temporary stay for travelers with a lunger Khana to serve free food to devotees.

Baba Bhuman Shah declared Baba Nirmal Chand his successor by putting tilak to take care of Dera. Smadh of Baba Bhuman Shah was constructed by Baba Nirmal Chand which was declared as National Heritage in 2008. Although, other structures such as Darbar Baba Sri Chand, Smadhs of Nirmal Chand and other Mahant, Thara, Nishan sahib and Deory are not significant, but they are within 200', they will have to be protected as per Antiquity Act 1975.

The whole complex is a miracle of art and architecture and needs to be studied but due to the limitations, the research has been specified to the Gurdwara. But I can be studied in future.

\section{Location \& Context of the selected Area}

The complex is located in the village Bhuman Shah at a distance of $24 \mathrm{~km}$ from the Haveli Lakha Road, Dipalpur, District Okara. As per record of Revenue (A report of Evacuee Trust Punjab Board prepared in 2005), total area of the selected site is 19 Kanals and 02 Marla's. The religious complex is surrounded by other structures associated with the saint.

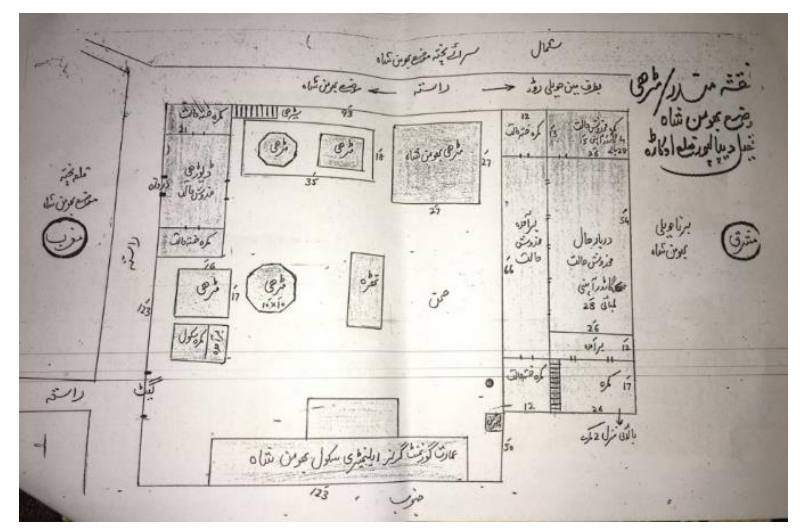

Map 2 Plan of the Gurdwara Baba Bhuman Shah Complex prepared by ETPB in 2005

- Fort/Qila Baba Bhuman Shah is in front of the entrance.

- Haveli Baba Bhuman is on the back side of the Gurdwara.

- There is a Sarai for residence of the visitors on the North side

- There is an elementary school on the southern side.

\section{Inheritance of the Dera}

Baba Bhuman Shah left a huge property on the name of Dera. He died in 1747 and this was the time when sixth Guru Gobind started his struggle to survive, and it is the time of supremacy of Udasis. Swami Chandra states in his book "Mirror of Bliss, In the period of sixth Mahant Baba darshan Das, British Divisional Commissioner attached a huge agricultural land of almost 3000 acres to admire the personality of Baba Darshan Das. In case of property, this Dera is the richest in Pakistan. As per records of Evacuee trust Punjab Board, the total area of the Dera is 242 Kanals and 12 Marla's. Out of which 19 Kanals and 02 Marla's are dedicated to the religious building. A part of it has been spared for the elementary school. The Dera is under the administration of Evacuee Trust Punjab Board. Shrine is in the form of ruins and not operational as Udasis has been moved to India. After moving to 
India, they seldom came to pay homage to Baba and shifted their properties to India also. However, they came in Pakistan in 2009 to celebrate mela with the permission of Evacuee Trust Punjab Board.

\section{Master Plan of Gurdwara Baba Bhuman Shah}

In the selected area there are certain buildings which are in the enclosure of the Complex.

1. Samadhs of Baba Bhuman Shah

2. Samadhs of other mahants

3. Darbar Baba Sri Chand

4. Darshani Deori/Gateway

5. Nishan Sahib

6. Thara

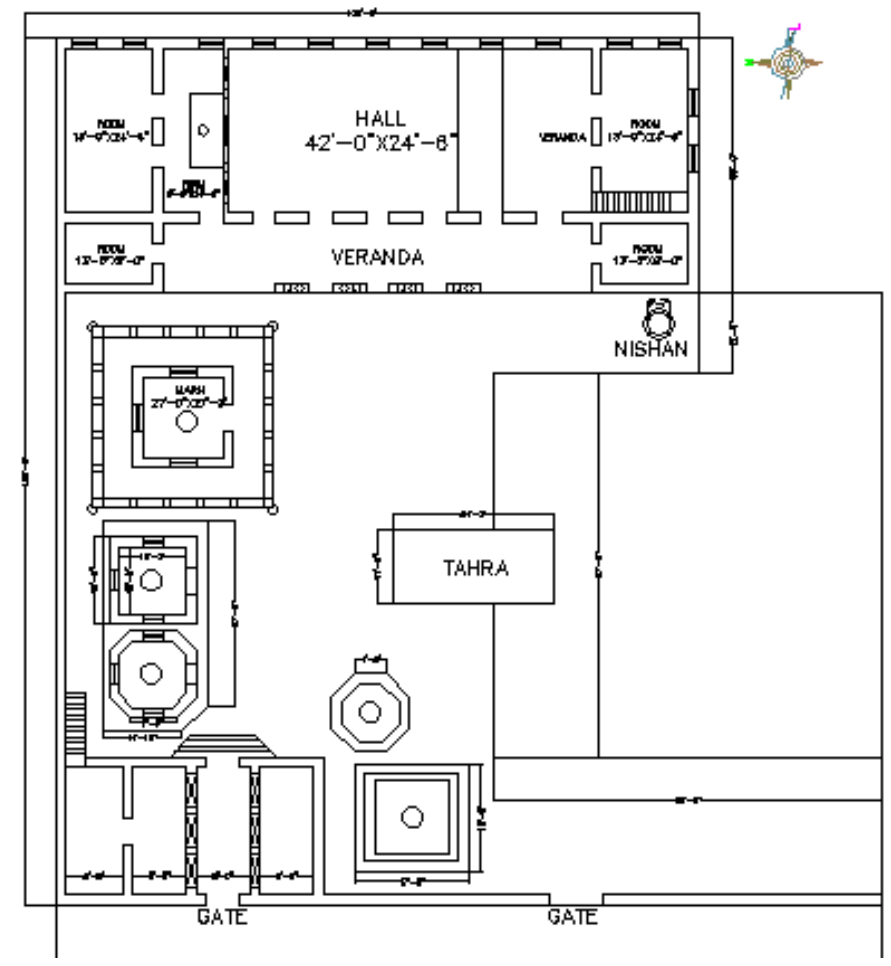

Map 3 Detailed map of Gurdwara Baba Bhuman Shah Complex Source: Drawn by Author

\section{Smadh of Baba Bhuman Shah}

The Smadh of Baba Bhuman Shah has been declared as National Heritage in 2008 by the Government of Pakistan. It has been constructed by the Baba Nirmal Chand, successor of Baba Bhuman Shah. It is a double story building, burial place of Baba Bhuman Shah. Saint spent all his life as sadhu and served the humanity. According to the rituals of the Udasi Panth, Samadhas are part of Gurdwaras. After the declaring Udasis as non-Sikhs, their Gurdwaras are termed as Mandir as Udasis are closer to the Hinduism and lies in between Sikhism and Hinduism (Baig, 2016).

The Smadh of Baba Bhuman Shah is currently not recognized by the Sikhs as Sikh Gurdwaras. The dispute is still undecided and Udasis went to legal judgements of the courts but still, they have been failed to prove themselves as Sikhs due to the worship of idols and believe in Hindu five gods. Pictures of Hindu gods can be visualized on the ornamentation of their buildings (Qaiser, 1998). 


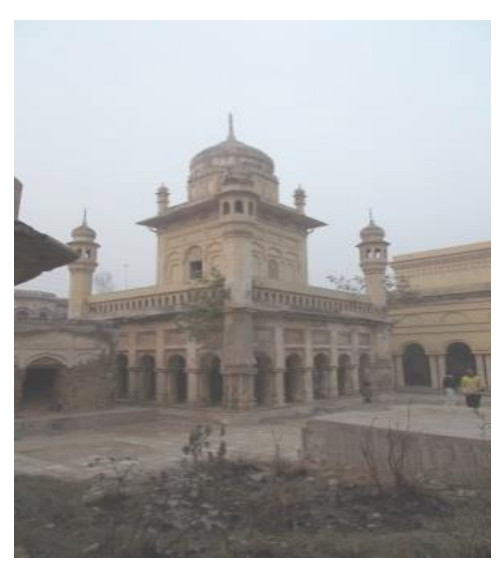

Figure 2 View of Smadh of Baba Bhuman Shah Source: Drawn by Author

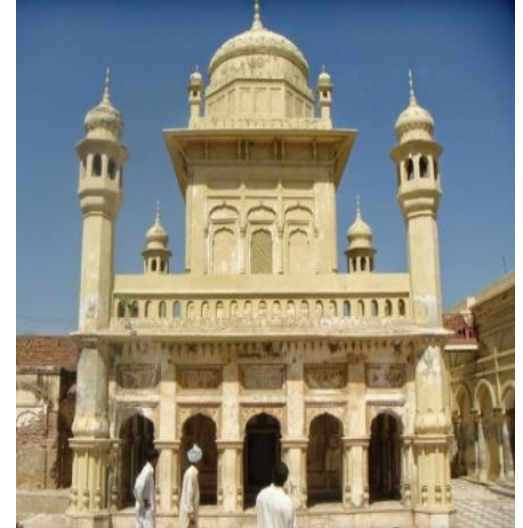

Figure 3 Façade of Smadh Baba Bhuman Shah Source: Drawn by Author

Smadh of Baba Bhuman Shah is square in shape with four minarets, on each corner and a central dome over the cemetery of saint. His ashes have been buried in the central part of the monument. There are four entrances on all four sides. A colonnade is running on all the four sides of the Smadh with a 6' wide corridor running along the burial place of the saint. The burial chamber of the saints remains is of 14 'x 14 '.
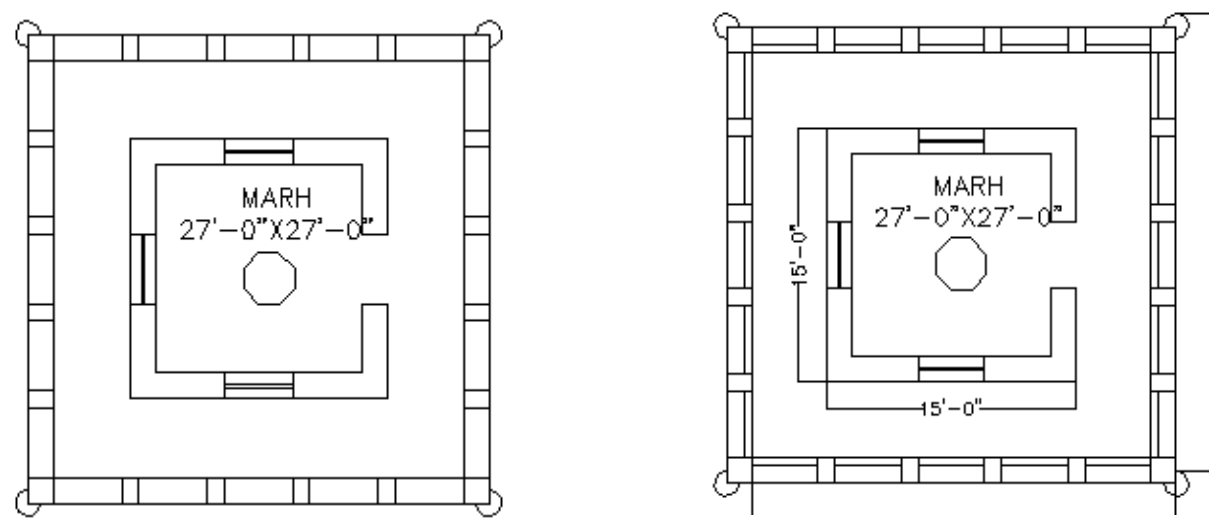

\section{Map 4 Ground Floor \& First Floor Plan of Smadh Baba Bhuman Shah \\ (Source: Drawn by Author)}

Central octagon is the burial place of the saint's ashes, and an octagonal column is running in the center of room to avoid the disrespect to the saint's remains and also avoid the place from the human footsteps. However, at first floor level, a podium of low height has been developed to mark the place of securing ashes of the saint.
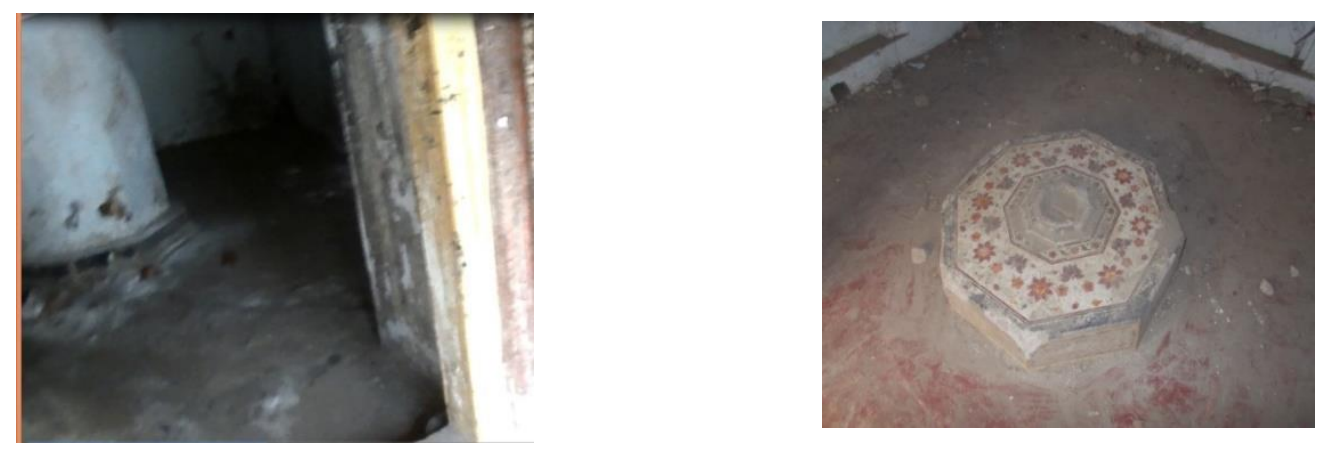

Figure 4 view of Ground \& First Floor showing place of Remains of saint (Source: Author) 


\section{Art and Architecture of Samadhs Baba Bhuman Shah}

There are four Chhatris to ornament the parapet. A beautiful fluted dome, arches in the wall and mural art of the ceiling characterizing its architectural styles represent Sikh Smadh architecture. The wall decorations characterizing with the floral patterns and animal motifs. These mural paintings are too rich like Persian carpets, the naqasher or painter has composed unique style of painting showing floral paintings, animal activities and Hindu gods.

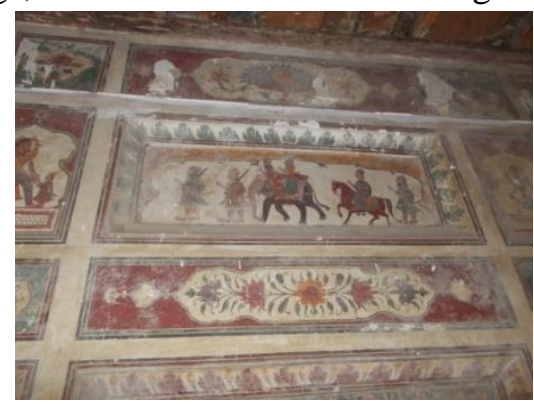

Figure 5 Ornamentation showing animals

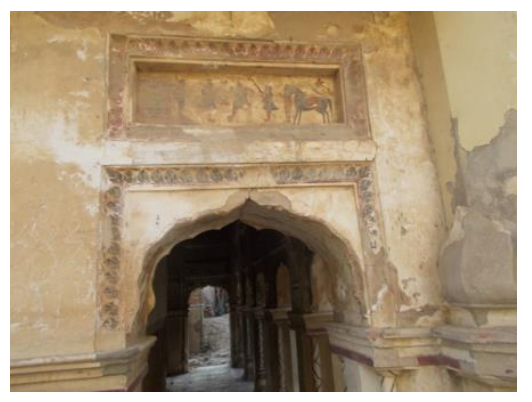

Figure 6 Colonnade of Smadh \& human figures

Around the central room, there are verandahs and the walls of the verandahs are showing rich ornamental details. There are mural paintings which shows Sikh movements and historic events.

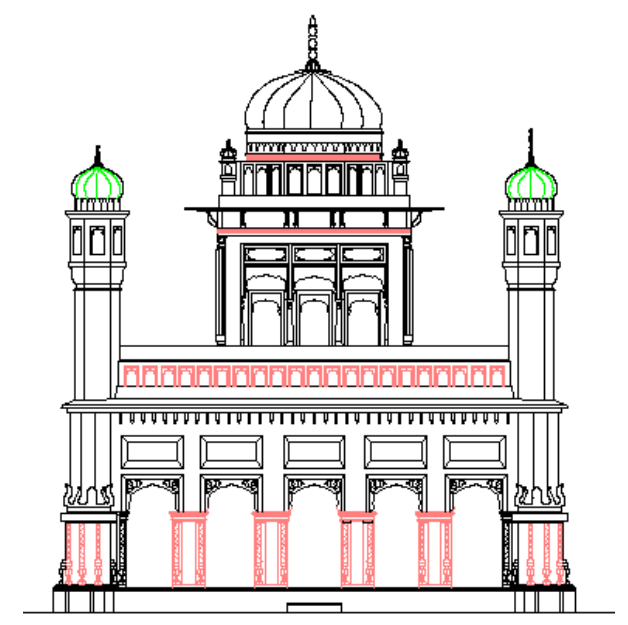

Map 5 Elevation of Samadhs Baba Bhuman Shah Source: Drawn by Author

One of the important media of painting is Dahin to show the imaginations, base of Dahin is Gharwan, a decorative device involving knotted grapple between the animal. Roof of the monument has been decorated with wooden carvings with geometric patterns. The technique of the paintings showing human figures showing on the back of the horse is termed as Kangra art. They are copied as the murals on the walls. Goch can also be seen on the walls. It is a technique to use stone in the form of paste like lime. There is no work of Tukri as no glass has been used.

\section{Smadh of Baba Nirmal Chand and Three Mahants}

At the time of his death, Baba Bhuman Shah gave charge of his Dera to Baba Nirmal Das. He was the person who constructed Smadh of Baba Bhuman Shah which is now a National Heritage declared by the Government of Punjab in 2008. Smadh of Baba Nirmal Chand is also constructed in the same premises opposite to the Smadh of Baba Bhuman Shah on the right side of the Deory. Name of Baba Nirmal Shah has been written in Gurmukhi on the entrance of the Smadh. There is a dome over the Chamber.
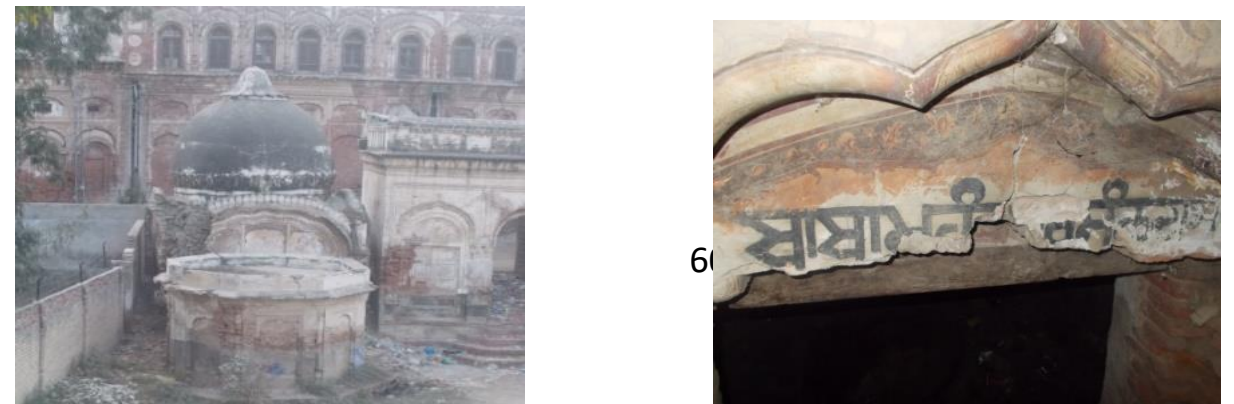
Figure 7 Smadh of Baba Nirmal Chand ( With Tomb)

The Smadh of Baba Nirmal Chand is of square of size 16' x 17' with a dome. An octagonal mark showing burial place of his remains is in the center of chamber. The decorations are painted in goch and the ornamentation inside the smadh of Baba Nirmal Shah based on the pictures of Hindu gods also.

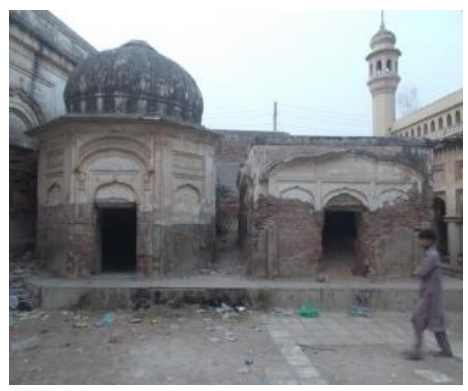

Figure 8 Smadhs of various Mahants

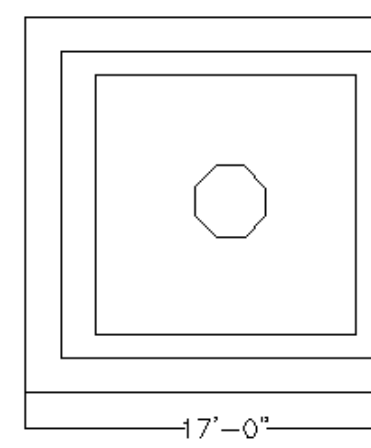

Map 6 Plan of Smadh Baba Nirmal Chand

Source: Drawn by Author

\section{Samadhs of other Mahants}

There are three other Smadhs in the courtyard. Two Smadh are aligned with the Smadh of Baba Bhuman Shah, and one is with the Smadh of Baba Nirmal Chand. But the names of the persons couldn't be recognized due to the bad condition of these monuments.
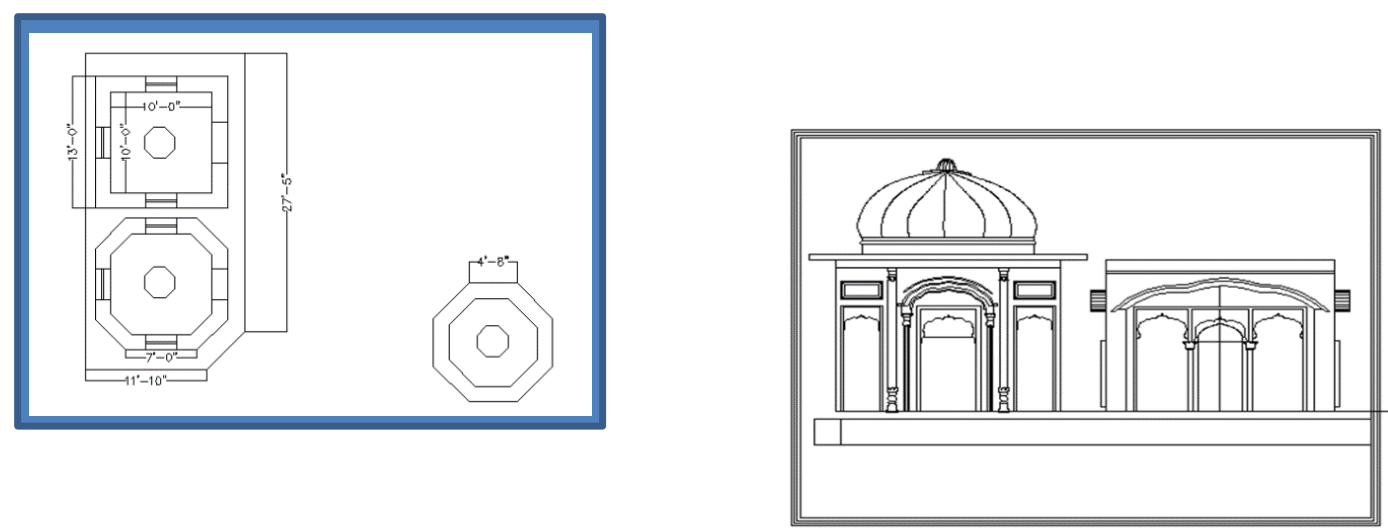

\section{Map 7 Plan of Smadhs of various Mahants Mahants}

Source: Drawn by Author

Map 8 Elevations of Smadhs of various

Source: Drawn by Author

The remains and their symbol are there in the octagonal form and no paintings are seen on the walls. The mural paintings are visible on the walls of the Samadhs. The painting is comprised of floral painting. Animals patterns and human Gurus mostly on the bac $\mathrm{k}$ of the horse. There are three other mahants who are the successors of Baba Bhuman Shah. One is octagonal and other two are square in plan. The octagonal has a dome similar to the Samadhs of the Baba Nirmal Chand but rest of the two are without domes. 


\section{Darbar Sri Chand}

The worship place at Dera Baba Bhuman Shah was named Darbar Baba Sri Chand and it has been built in 1910 on the proposal of Baba Harbhajan Das who was the ninth Mahant of Udasi Panth. This statement has been written on the face of Darbar.
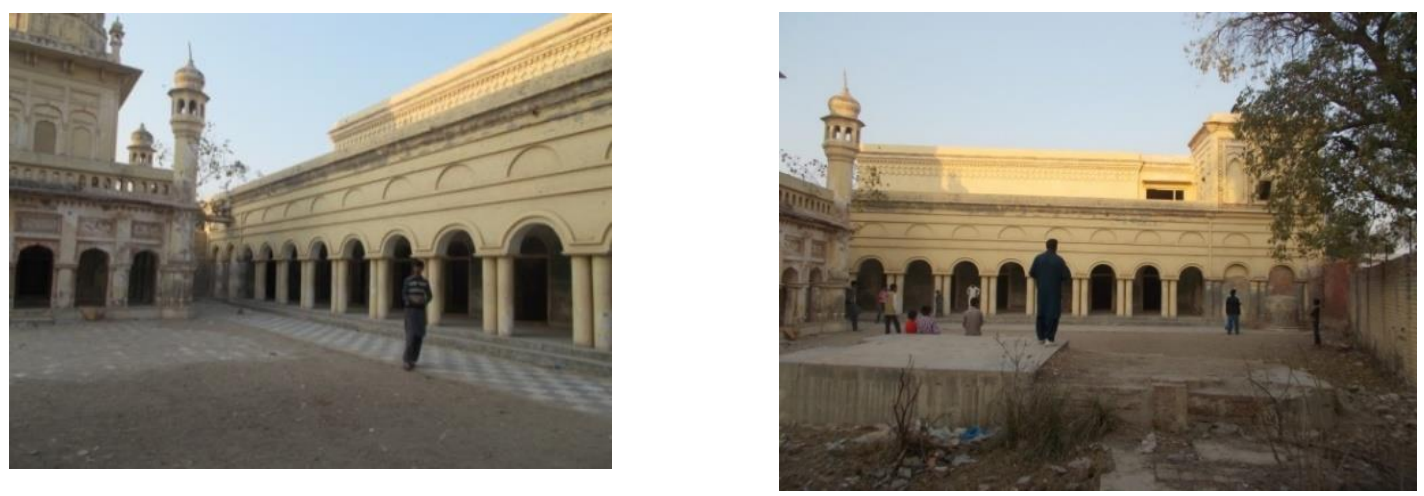

Figure 9 Darbar Baba Sri Chand (Gurdwara Baba Bhuman Shah)

It is double story building. The view of the building and type of arch used in the Darbar is also indicating that this building has been constructed during the colonial period. The architectural elements of this Darbar are closer to the British period and there is no traces of Sikh or Udasi period. As per Antiquity Act 1975, we have to save non-significant buildings with the declared National Heritage if they are in the close environment as the task of refurbishment is to save historic environment, not to individual buildings.

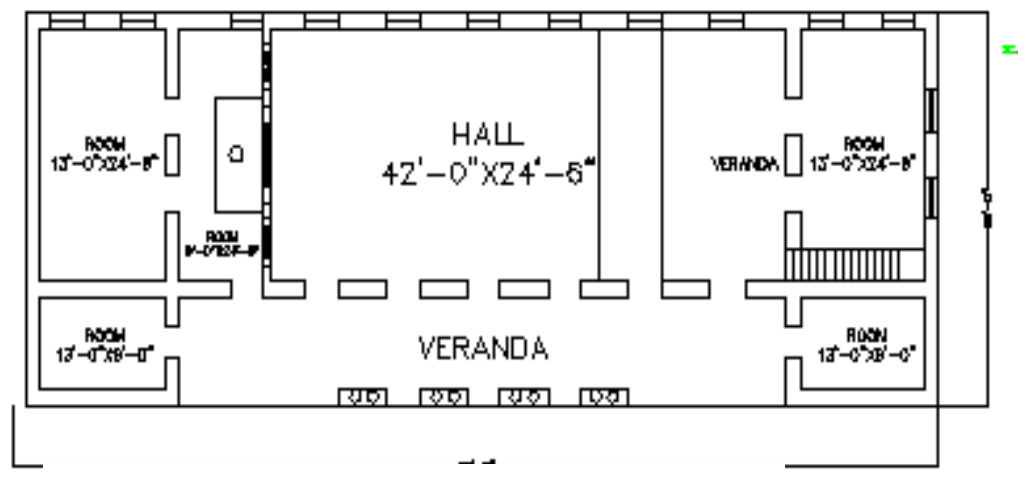

Map 9 Ground Floor Plan of Darbar Baba Sri Chand

Source: Drawn by Author

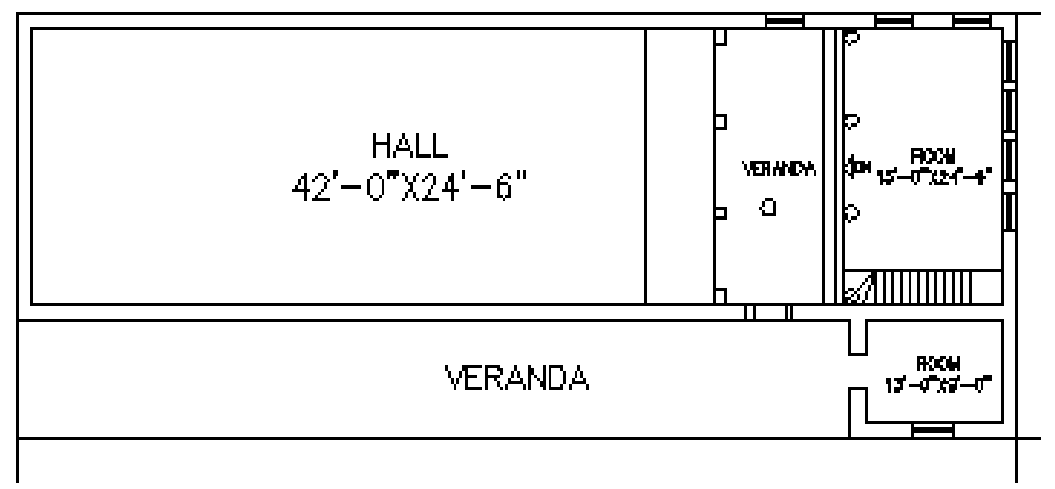

Map 10 First Floor Plan of Darbar Baba Sri Chand

Source: Drawn by Author

The covered area of the Congregation Hall is 2738 square feet ( $37^{\prime} \times 74$ '). The main entrance to the Hall is from the west side. On entering to the complex, Darbar is in front of us. There is a colonnade 
in the façade and there are small rooms on either side of the façade. There are six doors on the opposite wall of the façade. The congregation Hall is of double height making a clear view of Parkash Asthan captivating with dome, a place to have Holy Book. There are big rooms on North and South ends.

The eastern wall is adjacent to the Haveli Baba Bhuman Shah. There are four types of plans which are being used in Sikh shrines. There are certain areas which are mandatory parts of Sikh Gurdwaras.

- Parkash Asthan (Place for Holy Book)

- Sukh Asthan (Congregation Hall)

- Parikarma (path around Parkash Asthan)

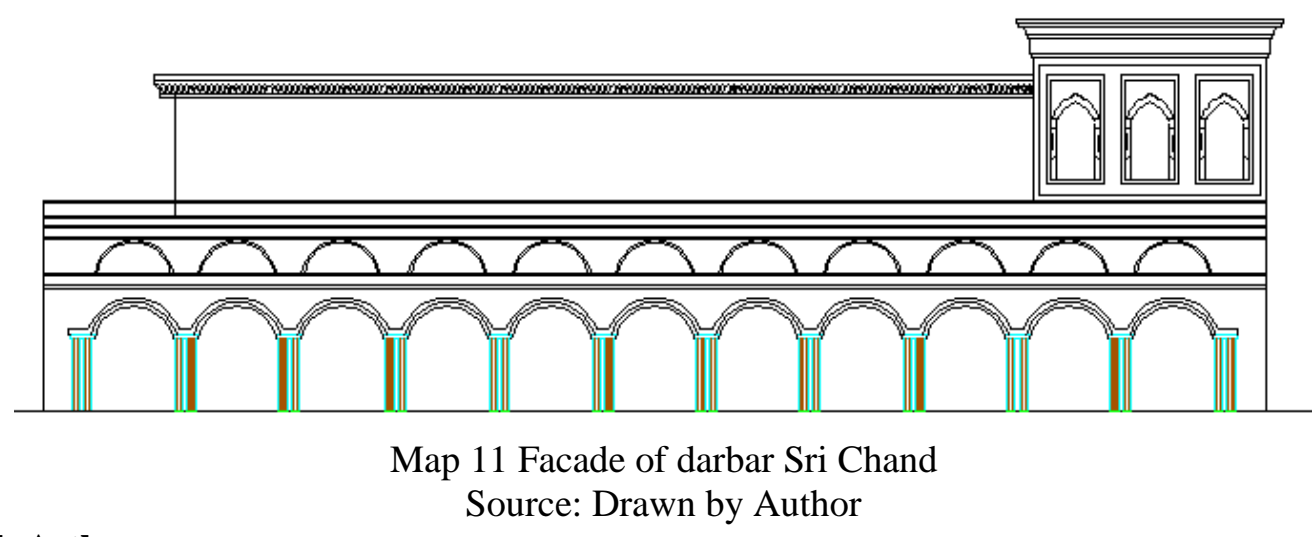

\section{Parkash Asthan}

It is located on the north end of the Sukh Asthan (congregation hall) which is rectangular. There is no typical shape, but it is related with the entrance. The span of the central arch is 10' and Parkash Asthan is at the back of this arch. Parkash Asthan has been divided into three parts with a dome in the central portion. Roof of the other two parts is flat 18 " but the dome is 2'-6".

The Parkash Asthan is 9' $\times 24 \frac{1}{2}$ ' including parikarma which is used to take the tawaf around Dasham Granth, placed in Parkash Asthan which is at the level of 1' -6 '. There are fresco paintings inside the captivated part and adjacent parts of Parkash Asthan.
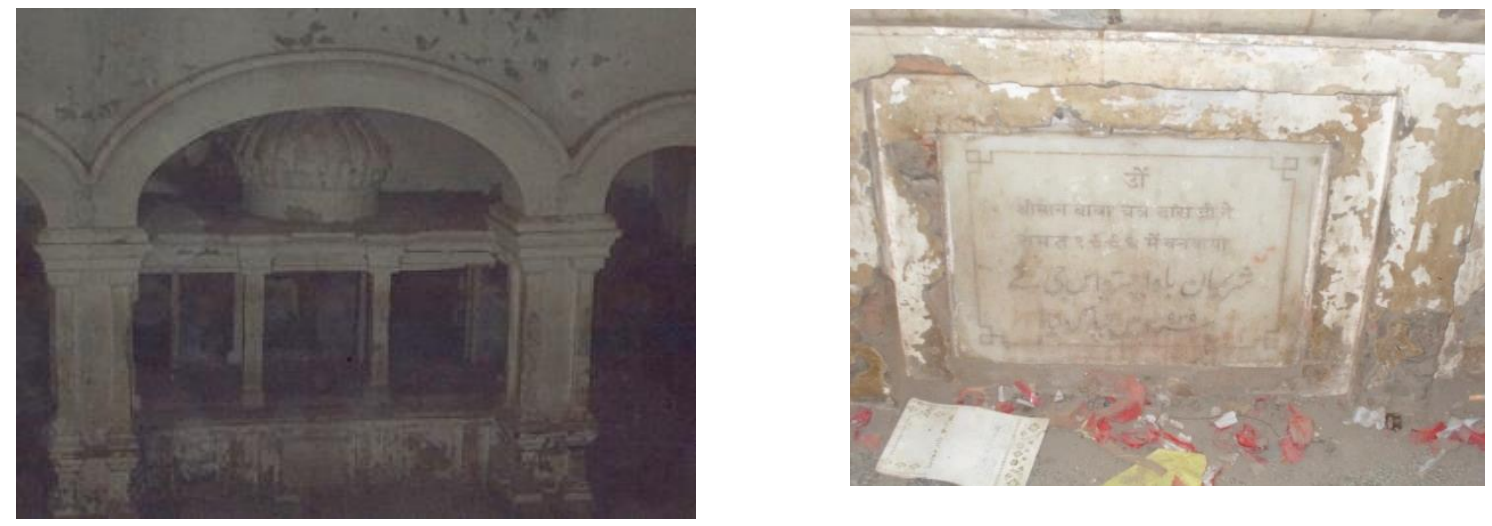

Figure 10View of the Parkash Asthan from the Gallery

This Parkash Asthan has been constructed by Shiriman Baba Chitter Dass in 1939. It has been written on a marble plate and put it on the face on the elevated plate form. The area of the Sukh Asthan is 1029 square feet (42'x 24'-6") 

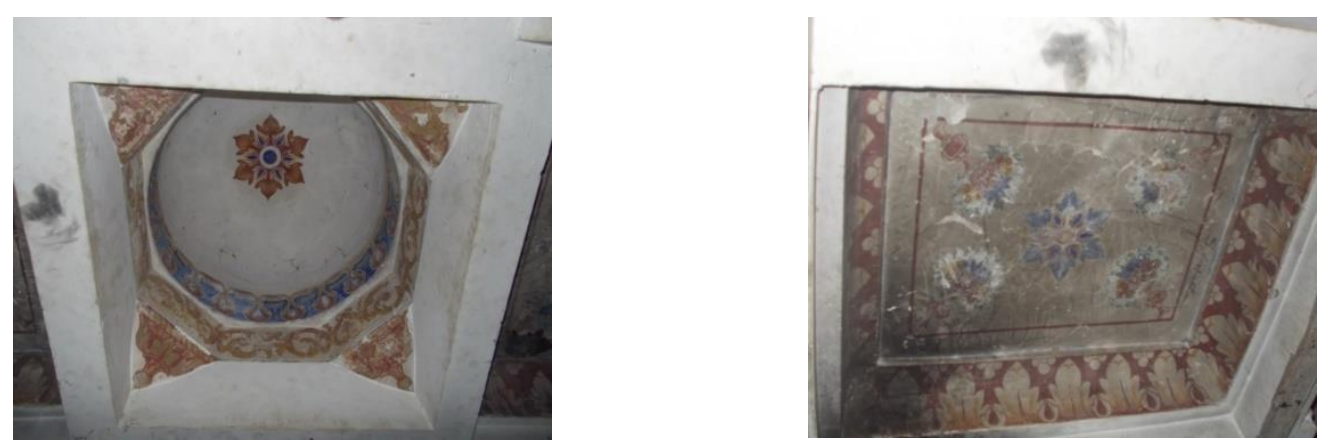

Figure 11 Floral paints inside the captivating dome of Parkash Asthan

There are rooms of the area 318.5 square feet (13'x $24^{\prime}-6$ ") on the north and south end of the Hall. There are rooms on the North and south ends of the colonnade adjacent to the Big rooms of the area 13 '-9" square feet (13'x8'-9'). The verandah is 10 ' wide.

\section{Darshani Deory/Gateway}

Darshani Deory / Gateway to the complex is showcase of Sikh architecture depicting frescos and paintings. It is a monumental gateway with an elegant wooden door. One of the panels has been detached and laying with side wall. Roof has been vanished. This gateway is chamber with offices on each side of the deory. These offices provide accommodation for the caretakers of the Dera.
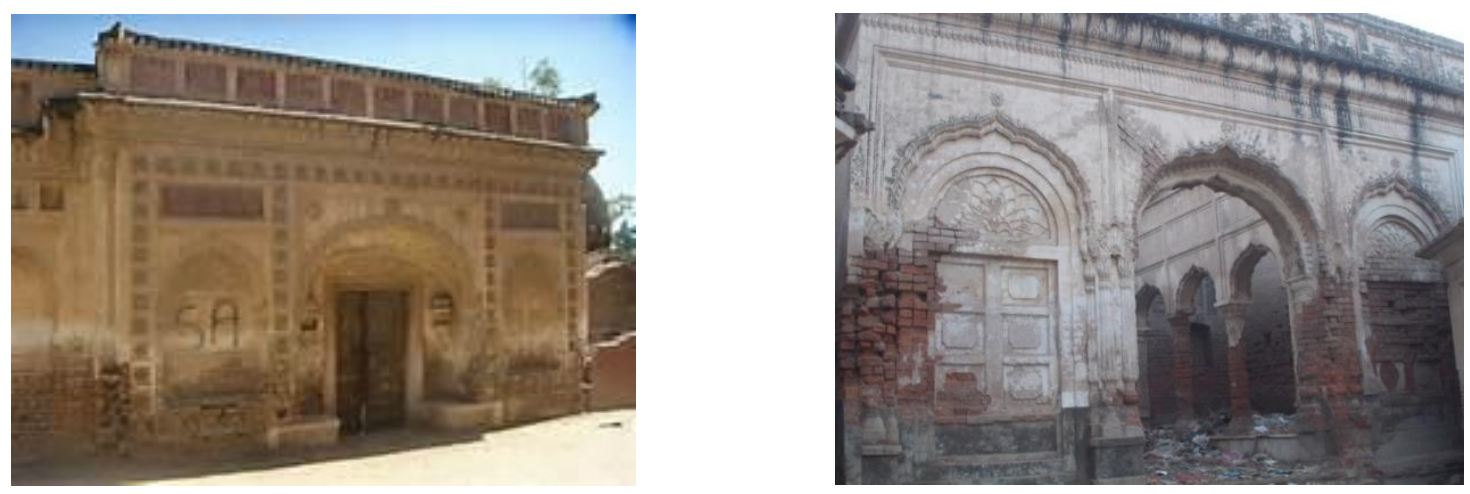

Figure 12External View of Deori Gurdwara Baba Bhuman Shah Ji Complex

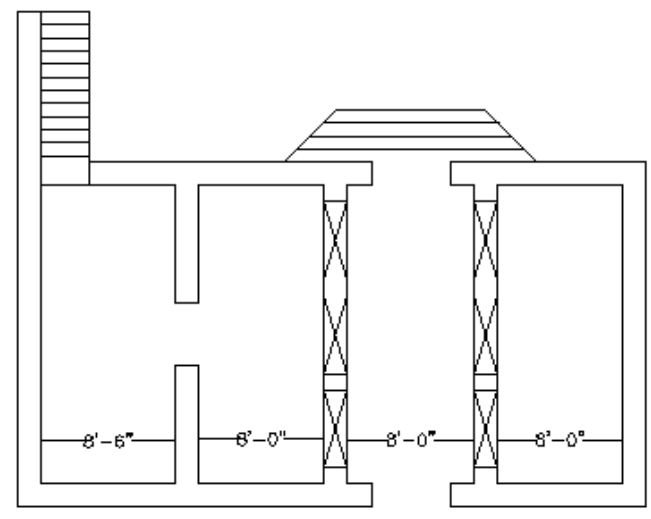

Map 1 Plan of Deori Gurudwara Baba Bhuman Shah Ji Complex 
This gateway has been constructed with the construction of Darbar Baba Sri Chand in 1910 proposed by the Har Bhajan Singh, Mahant of Dera at that time.as the arches are closer to Sikh architecture. The size of gateway is about $21^{\prime}$ wide and 19 ' in depth.

\section{Nishan Sahib}

Nishan sahib is a place to put the flag on it so that the travelers can recognize the Sikh Sarae/ Shrine from the distant place. Now there is a place of that flag, but flag is missing.

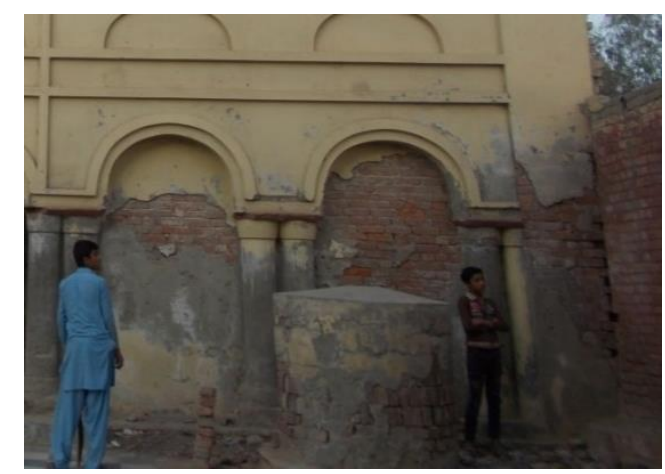

Figure 13 View of Nishan Sahib

\section{Thara}

There is a Thara in the center of the complex what is the purpose, nobody knows definitely, but the people told, that it was only to sit for preaching or meeting. The area covered by the Tharra 328 square feet is (24'x 12')

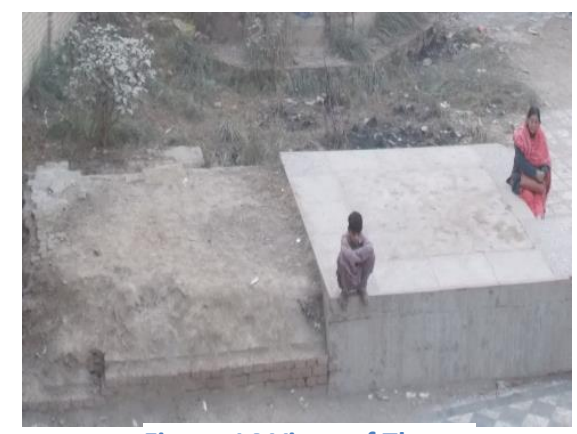

Figure 14 View of Thara

\section{Present condition of the monument}

The present condition of the monument is very poor and dilapidated. The monument has been tumbling down due to the several reasons which have been studied during the research.

There is no permanent caretaker of the monument, one leaf of the door has been down and lying on the southern wall of the Deori. Anyone can steal this door as there is no hindrance to enter into the complex.

The plaster of the monuments is deteriorating as there is no maintenance has been done after 2009. After the removal of the plaster, the bricks of the Smadhs have been started to deteriorate. They need urgently to be repaired. There are heaps of filth in the Deori, it is presenting the scene of filth center. The parapet of the monuments is falling and are without plaster. The dome has lost its pinnacle. The beautiful fresco murals are weeping on their condition of damage. The schoolboys and children of the neighborhood are playing in the premises. The overall condition of the monument is telling the story of the merciless society and care takers.

\section{DISCUSSION}

Historic monuments are index of the society and religious buildings represent the culture and norms of that society. The Gurdwara Baba Bhuman Shah is a holy place for the Udasi Clan. They migrated to India after independence and developed their Gurdwaras in Northern India. This Historic place is not only important due to its architectural and historic value but still it is pilgrimage for the Udasi 
Panth. This Gurdwara reveals the religious and ritual values of a clan who protected all the Sikh Gurdwaras during the period of assassination of Sikhs by the Mughals. Although, Udasis have migrated, but they celebrate mela every year to pay homage to the saint and people believe in the preaching of the saint for the good well in the life. Gurdwara is not operational, but it is of significant value, and it should be protected as a historic asset of Udasis and Pakistan.

\section{CONCLUSIONS AND RECOMMENDATIONS}

After investigating the architectural characteristics features and historic importance of the Udasi Heritage, it has been concluded that this national Heritage at grave threat to be vanished from the earth if it will not be saved. There is a need to protect this monument for the future prospective and for the preparation of conservation \& restoration of the site, opportunities to use it as adaptive re-use as, the Gurdwara is not operational but very important for the Udasi Panth. Congregation Hall may be used as library and the Smadhs are the only example of Udasi art and architecture. One can easily observed the images of Hindu gods in fresco. The piece of art is unique in the sense that Hindu gods in their picturesque style is important.

To manage and monitor the site, digital documentation and digital archive can support the stake holders. In nutshell, we can't allow anybody to destroy this piece of art and architecture. Government should take positive measures to protect it from the warm winds of contemporary's world.

\section{REFERENCES}

Arshi, P. S. (1986). Sikh architecture in Punjab.

Baig, A. U. (2016). webpage: http://aliusmanbaig.blogspot.com/2016/12/haveli-of-bhummanshah.html.

Bhatti, S. S. (2013). Golden Temple: Marvel of Sikh Architecture. Dorrance Publishing.

Britannica, T. Editors of Encyclopedia (2016, May 2). Udasi. Encyclopedia Britannica. https://www.britannica.com/topic/Udasi

Chahal, K. S., Dua, S., \& Singh, S. (2012). Architectural Evolution of Gurdwaras: An Overview. IUP Journal of Architecture.

Jokilehto, J. (2017). A history of architectural conservation. Routledge.

Kalhoro, Z. A. (2010). Hindu and Sikh Architecture in Islamabad and Rawalpindi. Journal of Asian Civilizations, 33(1), 88.

Kapoor, D. S. (2000). http://allaboutsikhs.com/.

Moon, A. T. (2016). http://dipalpur.blogspot.com/p/bhuman-shah.html.

Qaișar, I. (1998). Historical Sikh Shrines in Pakistan. Punjabi History Board.

Singh, A. (2016). Lost Heritage: The Sikh Legacy in Pakistan. Nagaara Trust.

. (2020). The control of sacred spaces: Sikh shrines in Pakistan from the partition to the

Kartarpur corridor. Sikh Formations, 16(3), 209-226.

Singh, K. (2014). Understanding Sikh Architecture through the Sikh Shrines in East Punjab. TheSikhEncyclopedia.com. (2000).

Udasi. (2020, March 11). SikhiWiki, . Retrieved 07:45, August 22, 2021 from https://www.sikhiwiki.org/index.php?title=Udasi\&oldid=117559.

Wikipedia contributors. (2021, August 28). Bhumman Shah. In Wikipedia, The Free Encyclopedia. Retrieved 02:29, October 11, 2021, from https://en.wikipedia.org/w/index.php?title=Bhumman_Shah\&oldid=1041149551

Wikipedia contributors. (2021, October 10). Sikhs. In Wikipedia, The Free Encyclopedia. Retrieved 02:48, October 11, 2021, from https://en.wikipedia.org/w/index.php?title=Sikhs\&oldid=1049227236

WorldGurdwaras.com. (2000). 